\title{
SOME HAUSA IDIOMS
}

To talk any language grammatically and correctly is always a worthy feat, but to speak it idiomatically with those intimate and elliptical colloquialisms that distinguish the talk of the natives themselves - this is the consummation of all your labours. Without these cunning tricks and turns of speech your conversation (I do not of course speak of the written language) will always lack the sparkle and lightness of the original, just as the still stagnant waters of a duckpond lack the ripple and glitter of a running stream. It is precisely these idioms which are most difficult to acquire, since in most cases you will scour your grammar in vain for any reference to them; but once learnt they will give an ease and a naturalness to your conversation which the dry bones of grammar can never quite furnish, and with these ready to your tongue you will probably find yourself accepted as a far greater scholar than may really be the case.

In the course of a year's intermittent study of Hausa, I have come across a good many phrases and modes of expression (some of which may perhaps hardly be termed idioms) which are fairly baffling to a beginner, and to which but little if any reference is made in the Text Books to which I have had access. I have here set down some of these phrases, most of them very common words or expressions, in English, in the hope that they may prove of some small use to other travellers on the same road, but I submit this little paper to the light of day in fear and trembling, and humbly beg that the chiefs of Hausa scholarship, should this reach their notice, may deal leniently with me.

Since Hausa itself presents so many variations of dialect, it is necessary to state that the phrases given are principally used in Kano, and I fancy would be understood as far round as 7aria, Katsina, Hadeija, and Hatagum, if not 
further; whether they have a still wider circulation, say as far as Zinder or Sokoto, I cannot be sure. Each particular district has its own special dialect of Hausa, called by the name of its principal town, as "Kanenchi," "Sokotenchi," "Katsinenchi," \&c. ; but the differences after all are not very apparent, consisting rather in pronunciation than construction, and I fancy I have given few if any phrases that would not pass muster wherever Hausa is spoken.

I. The words "never and "ever" in such common phrases as "Have you ever done so before" or "I will never do so again" are rendered by a use of the words "Taba" = to touch, and "Kara" = to add or increase, thus :-

(a) "I have never seen you before"= "Ban taba ganinka ba" (=lit.: "Have not touched seeing you").

"Have you ever been to Kano?"= "Kataba zua Kano?" (=lit.: "Have you touched going to Kano?").

(b) "You must never beat him again" = "Kadda ka kara dukansa" (=lit.: "Do not add beating him").

"I will never do it again"= "Bani kara yin hakka" (=lit. : "I do not add [or increase] doing so").

2. The suffix to the verb (it is not an ordinary tense or mood inflection as we understand it) is at first very puzzling. There are no less than five variable suffixes : $e, i, u, o$, and $a$; but it is very difficult to determine the exact significance of the $e$ and $u$, while of the remainder the $a$ and $i$ seem practically identical in meaning. The distinction between $a$ and $o$, however, is very marked; roughly speaking, the $a$ suffix is used to denote action not directly concerning the speaker, while the suffix $o$ invariably implies action towards or in close connection with the speaker, thus :-

Teffi $=$ go, but Teffo $=$ come.

Tashi $=$ get up, but Tasho=get up and come to me.

Tura $=$ push, but Turo= push towards me.

Dauka $=$ take, but Dauko $=$ take and bring to me.

The two words "Fitta"=come out and "Shigga"=enter illustrate this use clearly. If you are outside a room and wish a man to enter it you say "Shigga daki," but if you are inside 
and wish to call him in you say "Shiggo daki" ="come in to me." Similarly if you are inside a room and wish a man to go out you say "Fitta," but if you are outside and he is inside you say "Fitto" = "come out to me." One curious formation is found; Kira = to call has the form Kirao not Kiro; e.g., "Kiraoshi nun"="call him here to me."

3. The meaning of "in vain" or "useless" in such a phrase as "you've had a useless journey" or "what a waste of time !" is expressed by the word "banza" = worthless, useless-thus "You have had all your trouble for nothing"="ka ki aikin banza" (=lit.: "You have done a worthless work").

"If I get up it won't be for nothing"= "En na tashi ban tashi banza ba."

"It's a waste of time talking to you " = " $\mathrm{Ka}$ maida maganata a banza" (=lit.: "You turn my words to a worthless thing ").

4. For "before" the dictionary word "kan" is certainly used, but a good deal commoner phrase is "saa nŭn":"Shall we reach Katsina before rain comes?"="Ma kai Katsina saa nun ${ }^{3}$ ayi rua?"

"Don't come into my room before the sun gets up a bit"= "Kadda ka shiggo dakina saa nun rana ta hau summa."

5. "Enna," an invaluable word, means a good deal more than "where," to which it is generally restricted by beginners; it approximates equally to our "how?" and to our "what?" in certain phrases, e.g.:-

"How are you?"="Enna lafia?" (=lit.: "How is your health ?").

"How are your people?"="Enna giddanka?"

"What is your name?" = "Enna sunanka?"

"What is your news? = "Enna labari?"

"Where is the chief's house?"="Enna gidda'n sariki?"

"What is your town?"="Enna garinka?"

"What business is it of yours?"="Enna ruanka?"

"How far is the town we are going to?"="Enna kamman nisa gari inda zamu?"

\footnotetext{
1 Probably from the Arabic saa = "time." Mischlich gives saa-re-ran as equivalent to "about this time."-ED.
} 
6. For "how ?" I have never heard the dictionary word kaka used (though I am told it is to be heard at Katsina), and am informed that it is practically barred as an invidious or insulting word, only used to inferiors (it would be interesting to follow up the reason for this). The phrase I have always heard is "Enna yenda," thus :-

"How can a blind man find the road?"= "Enna yenda makafo yi ke duba hainya?"

"How shall I do this?"="Enna yenda zan yi hakka?"

7. The conditional phrase "If I had __, I would have__-" is so admirably treated in Dr. Miller's excellent little manual that it is unnecessary to do more than mention it with one example:- "If I had known, I would not have done so"= "Da na sani, da ban yi hakka ba."

8. A common phrase in English is turned thus :-

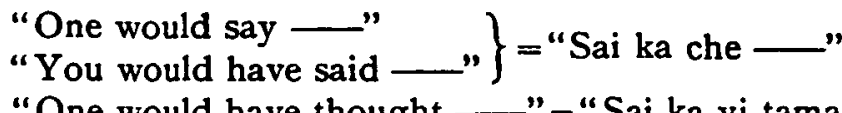

"One would have thought ___" "Sai ka yi tamaha."

"I should have thought _- " "Ko na yi tamaha."

The Hausas have an odd turn for "business" or "affair" in such a phrase as "None of my business"; they use "rua" $=$ water, thus:-

"It's not my business" = "Ba ruana ba."

"What's it got to do with him?"= "Enna ruansa?"

10. The absence of any proper comparative is one of the weakest spots in the language. The English comparative and the kindred phrases "Too many," "Too good," \&c., can only be rendered by use of the verb "fi "= to surpass or excel, and

1 Mischlich (Wörterbuch der Hausaspracke, s. v. ma, p. 409) says that the Hausas explain this idiom by the following tale: "Two men once went to the bosh :-one had a lump of fura (a kind of dumpling made from Guinea-corn, which has to be soaked in milk or water before eating), and the other a calabash of water. When they grew hungry, they mixed the fure with the water, and then quarrelled as to who should eat first. Some people came along and asked what the quarrel was about, and when they had heard, asked further, to whom the fura belonged. A. said, 'It was mine,' and B. added, 'But the water was mine.' The arbitratnrs then asked $A$. 'Akoi ruansa chiki?' = 'Is his water in it?' $A$. replied 'Ruansa' $=$ 'The water (is) his. They replied 'Ruansa'=meaning : 'Then it is his affair,' and added 'Fura-1-ku che'='the fura is for both of you." So they divided it and ate."-ED. 
over and over again the beginner will find himself hampered by this irksome limitation, which, turn it as you will, affords but a poor substitute for our comparative; other words are sometimes brought into use :-1

"He is cleverer than you "= "Ya fika hankali" (=lit. : " $\mathrm{He}$ surpasses you as to sense").

"This load is heavier than that"= "Kaya nun ya fi wonchan noyi."

"This town is bigger than that" = "Gari nun ya fi wonchan girma."

"It's too heavy for you "= "Ya fi karifinka noyi" (=lit.: "It passes your strength as to heaviness").

"He is older than you" = "Shekarasa ta fi taka" (=lit.: "His years pass yours").

"You have given me more food than I want" (or "too much") = "Ka bani abinchi wonda ya yi yawa" (=lit.: "You have given me food which makes plenty").

"Which of the two villages is the farther?"="Achikkin gari nun biu wanene ya fi nisa?"

"This is smaller than that" ="Wunan ya fi wonchan karami."

"It's too high for me" = "Ya fini tsoho."

"It's too difficult for me"

"I want more men than last time" = "Ina so mutane woddanun suke fi na da."

"This is too small, give me a bigger one" = "Wunan ba ya issheni ba, bani wonda ya fi girma."

"You have stayed too long" = Ka dedde a teffia" (=lit. : "You prolonged or delayed going").

"I have been in this town longer than you" $=" \mathrm{Na}$ fika deddewa a garinun."

The possessive particle "maï" holds a high place among Hausa idioms; it is so serviceable that one can only regret we have no similar construction in English. "Mai" sometimes shortened to "ma" means "the owner of:" or "the man

This is a common idiom in the Bantu languages-e.g., Chinyanja use of kupita= to pass, and kupanibana = to surpass or excel.-ED. 
who has," and may be prefixed to any word or group of words; the plural is "masu," and there is no difference for feminine words : -

"The owner of this"= "Mai-wunan."

"The man who has it" = "Mai-shi."

"The man who is carrying water"= "Mai-kai-rua."

"The man who is eating meat"= "Mai-chin-nama."

"Who is the owner of these fowls?"= "Wanene mai-kajiwoddanun?"

"Where is the man who knows the road?"="Enna maisannin-turba?"

"Murderer" = "Mai-kasshe-mutum."

"Who does this calabash belong to?"="Wanene maikwaria-nun?"

"The men who are repairing the road"="Masu-garanhainya."

"The Hausas are a troublesome race (?)" = "Hausa maiban-haushi" (= lit.: "Hausa (is) master of giving anger"). This last example is interesting as containing a near approach to a pun; it is a kind of proverb. ${ }^{3}$

Any intransitive verb is given an active force by the addition of the preposition "de" followed by the objective, thus:-

Teffi $=$ Go. Teff de shi="Take it away" or "Make him go."

Tsaya = Stop (intr.). Tsaya de su= "Stop them."

Sauka $=$ Descend, get down. Sauka de shi="Bring it down."

Zona $=$ Sit down. Zona de shi = "Make him sit down."

Komo $=$ Return. Komo de shi= "Bring it back here."

Sukwa = Gallop. Sukwa de su = "Make them gallop."

Tashi $=$ Get up. Tashi de shi = "Make him get up."

13. There are two enclitics or particles in wide use which demand the consideration of anyone anxious to master

1 We may remind readers familiar with Swahili of the useful idiom which in that langrage helps to make up for the lack of adjectives proper. The word-enyi= " having," or "owner of" is used much like mai in Heusa : mtu mwenyi nguvu= "a strong man" (lit: owner of strength"); chombo chenyi muiringo $=$ "a round pot"; pahali penyi maji="a wet place."-ED. 
idiomatic Hausa. They are "ai" (pronounced like English vowel " $i$ ") and "dei" (pronounced "day"); they are quite redundant and have no meaning; they are not, I fancy, mentioned in any of the Text Books, and would probably be denounced as vulgarisms; but that they are frequently heard no one who has listened to Hausas in conversation for even a few minutes could possibly deny. The people themselves speak of their use as "full Hausa" or "filling-up Hausa""chikkan Hausa"; these particles are simply placed at the close of any sentence, positive, negative, or interrogative, but they have no interrogative signification, like "ko" and "ba":-

Q. "Are you going to the market?"="Zaka kasua, ai ?" A. "Not just yet "= "Tukuna, dei."

Q. "Have you finished your work?"= "Ka gamma aikinka?"

A. "Yes"="Na gamma, ai."

Q. "I am going for a ride now" = "Yanzu na hau doki, ai."

A. "I will come with you" = "Zani tare, ai."

Q. "Have they brought food yet?"= "Ankawo tuo, ai ?"

A. "It is coming "="Akawo, dei."

These examples may seem very trivial, but I have purposely dwelt on the point, as these particles, which are of the very essence of idiomatic Hausa, are, as far as I have noticed, quite ignored by Europeans.

14. "Tukuna" is, I should imagine, a unique word in this or any language, and quite deserves a special paragraph; it is used equally with a positive or a negative sense, how may be seen best from the examples:ko?"

Q. "Are you going home now?"="Yanzu zaka gidda

A. "Not yet"= "Tukuna" (or "Tukuna dei").

"I am coming in a few minutes"= "Ina zua tukuna."

This use is possibly elliptical, and stands for-"Ina zua amma ba tukuna ba "= "I am coming but not yet."

"Leave it for the present" = "Abershi tukuna."

"Wait till I come just now" = "Sai na zo tukuna."

"He has not come yet "= "Ba ya teffo tukuna ba." 
"Better shut the gate presently"="Sai ka rufe kofa tukuna."

"Stop a moment" = "Tsaya tukuna."

"You drink first" = "Sha tukuna."

"Not for a few minutes" = "Sai tukuna."

An ever yawning pitfall for many of my countrymen (Scotsmen and Irishmen would naturally avoid it with less difficulty) is the rolling of the letter " $R$," which in Hausa has to be given its full value. It may seem quite superfluous to make this point, but we as a race are so apt to disregard the letter " $R$," especially when it precedes another consonant, that a beginner easily makes mistakes in Hausa; e.g., he would pronounce "sarka"="chain," the same as "saka" = "to weave"-he would at first naturally take no more notice of the "R's" than he would in the English word "armour" say, or "torture." The mistake is intensified in many words by the natural difficulty we have in realising the broad sound of the vowel " $A$ " in most foreign languages; such words as jāki, kilāgo, hāderi, some are at first tempted to write (and to think of as) jarki, kilargo, harderi.

It might seem an unnecessary precaution, yet it would often be safer either to write a double " $R$ " or to ensure its full value by inserting an $i$ or e after it:-

Dakirr, harr, merrda, birrni, or mereda, birini. The pronunciation is equally marked if concluding " $R$ " is followed by a consonant ; this frequently occurs since the feminine possessive termination is " $R$," e.g.:-Kofar(r)gari, kasar(r) kano, sabor(r) hainya.

The characteristic use of the word "da" = "son," is perhaps worthy of mention. It is of course found extensively with its own meaning of "son," being used to describe the young of practically all living creatures, e.g. :-Da'n akwia = kid. Da'n karre $=$ puppy. Da'n doki $=$ foal. Da'n tsuntsu= young bird. But from this it has come to mean "anything small," and is largely used in place of the adjective "small" (= kankane or karami), thus :-

Da'n kasua = small market.

Da'n akwati = small box. 
Da'n demmi'n dawa $=$ small bundle of guinea corn .

Da'n daki = small room.

Da'n wondo = short pair of trousers.

Da'n tsofo= little old man (not "son of the old man ")

If the word is feminine use "ya" = daughter, with of course the possessive " $R$ " not " $N$ " (which is masculine only) :-

Ya'r fitilla = a small lamp, or, a small piece of candle.

Ya'r riga = a small shirt or robe.

Ya'r kwaliba =a small bottle (as for scent, \&c.).

Philip V. King, M.A. (Oxon.), District Commissioner, Kano, S. Nigeria. 